\title{
MANAJEMEN STRATEGI ANALISIS SWOT DALAM MENGHADAPI PERSAINGAN BISNIS PADA BMT NU PUSAT GAPURA SUMENEP
}

\author{
Misba Huddin \\ mhuddin112@gmail.com \\ Universitas Ibrahimy Situbondo
}

\begin{abstract}
ABSTRAK
SWOT analysis is a form of analysis within company management or within organizations that can systematically assist in the preparation of a mature plan to achieve goals, both short-term and long-term goals. This analysis must be applied by a company. The purpose and benefits of a SWOT analysis are to combine four factors or compositions accurately on how to strangth, weaknes, opportunities and threath. The SWOT analysis method can be considered as the most basic method of analysis, which is useful for looking at a topic or a problem. To facilitate understanding in this study, researchers used qualitative research methods. The data obtained by researchers in the field include interviews with leaders of BMT NU Pusat Gapura Sumenep to find out strategies to face business competition. In addition, the data collection techniques were carried out by researchers by means of interviews, observation and documentation. In this study also, the presence of researchers is very important because researchers are human instruments as well as data collectors
\end{abstract}

Keywords: Analisis Swot, Persaingan Bisnis

\section{PENDAHULUAN}

Dalam kajian Islam, ada banyak hal yang menjadi fokus pembahasan, serta memberikan tuntunan pada seluruh aspek kehidupan, baik hubungan manusia dengan Tuhan, atau manusia dengan sesama manusia. Inilah yang sering disebut dengan implementasi Islam secara kaffah (menyeluruh). Terhitung mulai pembahasan pada halhal bersifat mikro hingga pada yang makro, dari yang khusus sampai yang umum, bahkan dari yang terlihat (realita) hingga yang tidak terlihat (transparan).

Manajemen syari'ah telah ada sejak kehidupan ini, yaitu sejak zaman nabi adam hingga zaman Rasulullah SAW. Sebenarnya dari awal Islam telah mendorong umatnya untuk mengorganisasikan setiap pekerjaan dengan baik. Pembagian tugas-tugaspun telah dilaksanakan(Nana Herdiana Abdurrahman, 2013). Walaupun Rasulullah SAW tidak menyatakan bahwa hal ini sebagai proses manajemen, aspek-aspek manajemen 
telah dilakukan,misalmya alasan beliau untuk tidak mengangkat Umar bin Khatthab sebagai panglima perang karena ternyata memang beliau mengarahkan umar bin khatthab sebagai seorang negarawan.

Dalam perkembangannya kita melihat bahwa sampai dengan akhir abad ke-20 hampir semua negara didunia terlibat denga isu ekonomi, tekhnologi dan keamanan dan sekaligus merupakan masalah yang dikembangkan diseluruh dunia. Memasuki abad ke21 atau juga yang dikenal era globalisasi, sebagai era tanpa batas yang tercermin dengan adanya kebebasan dalam berusaha, kebebasan dapat berpendapat, dan dalam bersaing dalam praktis tidak ada lagi batas antara satu dengan negara lain. Kebebasan berusaha sudah menjadi tuntutan semua masyarakat diseluruh dunia.

Seiring berjalannya bisnis yang semakin pesat, banyak produk yang telah diproduksi untuk bersaing antara satu produsen dengan produsen lainnya. Dengan demikian, perusahaan dituntut kreatif dalam menciptakan produk pemasaran produk atau jasanya. Para pelaku berlomba-lomba melakukan berbagai cara ataupun strategi untuk memepertahankan usaha dan bersaing dengan usaha yang lain. Oleh karena itu, diperlukan strategi terencana agar dapat menghadapi pesaing dengan baik.

Dengan demikian, manajemen sebagai ilmu dan seni mengatur proses pendayagunaan strategi bersaing yang baik untuk mencapai tujuan perusahaan. Dalam era globalisasi, isu yang paling banyak dikembangkan adalah isu persaingan global. Artinya, isu utama era globalisasi adalah kebebasan berusaha yang kemudian dipacu dengan persaingan bebas yang tidak ada lagi batasannya dalam suatau wilayah atau negara tertentu. Kebebasan berusaha ini telah menjadi tuntutan dan kebutuhan masyarakat dunia dari strata manapun mereka berada. Dengan demikian, dalam era persaingan bebas ini peran pemerintah semakin berkurang terutama dalam perekonomian dengan berbagai proteksi baik pada badan usaha milik swastamaupun usaha milik negara. Dalam berbagai kegiatan setiap negara telah siap dan mulai melaksanakan serta memperbaiki inftastruktur ekonomi yang diperlukan untuk dapat memperkuat posisi negara dan pelaku ekonominya agar dapat bersaing dipasar global(Veithzal Rivai, 2004).

Dalam rangka persaingan ini organisasai atau perusahaan harus memiliki sumber daya yang tangguh. Sumber daya yang dibutuhkan untuk menjalankan perusahaan tidak dapat dilihat sebagai bagian yang berdiri sendiri, tetapi harus dilihat sebagai satu 
kesatuan yang tangguh membentuk suatu sinergi dalam masalah angkatan kerja, di era globalisasi ini atau pada zaman milenial ini akan terus berubah dengan cepat dan dramastis.Dalam era globalisasi yang ditandai dengan derasnya arus informasi dan cepatnya mobilitas manusia, modal, barang dan jasa, semakin terlihat pula sifat ketergantungan dan sekaligus persaingan yang tajam antar bangsa.

Persaingan merupakan inti dari keberhasilan atau kegagalan dari suatu perusahaan. Keberhasilan atau kegagalan perusahaan tergantung dari kemampuan mereka menerjemahkan dan menginterpretasikan strategi bersaing yang telah direncanakan sebagai tindakan dari perusahaan dalam menghadapi ketatnya persaingan didunia bisnis. Strategi bersaing itu sendiri merupakan pencarian posisi bersaing yang menguntungkan di dalam suatu industri, arena fundamental tempat persaingan itu terjadi (Veithzal Rivai, 2004).

Strategi bersaing bertujuan menegakkan posisi yang menguntungkan dan dapat dipertahankan terhadap kekuatan-kekuatan yang menentukan persaingan industri. Kepulauan Madura khususnya di Sumenep memiliki sejumlah BMT NU yang memiliki standar kualitas pelayanannya masing-masing. Salah satunya adalah BMT NU Pusat Gapura Sumnep. Fasilitas yang ditawarkan oleh BMT NU Pusat Gapura Sumenep sangat menarik, baik dari pelayanan, akad serta lokasinya yang strategis juga merupakan faktor yang menjadikan BMT NU Pusat Gapura Sumenep sebagai pilihan tempat Simpan pinjam Masyarakat Pada kenyataannya data BMT NU Pusat Gapura Sumenep masih mengalami gejala fluktuatif atau tidak stabil dalam perekonomian masyarakat .Perlu ada upaya perusahaan untuk menentukan strategi bisnis, khususnya strategi bersaing di level perusahaan BMT NU Pusat Gapura Sumenep. Strategi bersaing diartikan sebagai strategi yang diimplementasikan perusahaan perbankan untuk mencari posisi yang menguntungkan dan berkesinambungan dalam industrinya.

Tidak dipungkiri bahwa lingkungan Lembaga Keuangan BMT NU Pusat Gapura Sumenep bersebelahan dengan lembaga keuangan lainnya, kedekatan posisi letak resort juga berpengaruh pada posisi persaingan. BMT NU Pusat Gapura Sumenep perlu melakukan identifikasi dan analisis lingkungan dalam bentuk Analisis SWOT. Tujuan pendekatan SWOT untuk mengetahui faktor kekuatan dan kelemahan internal serta faktor peluang dan ancaman eksternal yang dimiliki oleh BMT NU Pusat Gapura Sumenep dalam menghadapi persaingan. Agar Analisis SWOT efektif, perlu kiranya 
pendiri dan pemimpin perusahaan terlibat secara mendalam dalam hal ini karna tidak bisa dipungkiri bahwa tugas ini tidak bisa didelegasikan kepada orang lain. Akan tetapi, tidak baik pula jika haeus dilakukan seorang diri yang mana harus dikerjakan dengan bawahannya agar mencapai tujuan yang ingin dicapai. Karena, Perusahaan yang inovatif ialah perusahaan yang bahkan meliaht diluar jajaran internal mereka sendiri ketika melakukan Analisi SWOT dan mendapatkan masukan dari pelanggan atau nasabah untuk menambah ide-ide baru yang dapat masuk dalam pertimbangan suatu perusahaan tersebut. Dengan demikian, peran Analisis SWOT sangatlah penting bagi setiap perusahaan atau pengusaha agar apa yang diinginkan tercapai.

Dalam penelitian ini peneliti fokus pada pembahasan Bagaimana Strategi Analisis SWOTpada BMT NU Pusat Gapura Sumenep? dan Bagaimana Strategi dalam Menghadapi persaingan pada BMT NU Pusat Gapura Sumenep?. adapun yang menjadi tujuan utama dalam penelitian ini adalah untuk mendeskripsikan strategi analisis SWOT pada BMT NU Pusat Gapura Sumenep, untuk mendeskripsikan Strategi Dalam Menghadapi pesaing pada BMT NU Pusat Gapura Sumenep.

\section{KAJIAN TEORI}

\section{Analisis SWOT}

Analisis SWOT adalah suatu bentuk analisis di dalam manajemen perusahaan atau didalam organisasi yang secara sistematis dapat membantu dalam usaha penyusunan suatu rencana yang matang untuk mencapai tujuan, baik itu tujuan jangka pendek maupun tujuan jangka panjang. Analisis ini yang harus diterapkan oleh suatu perusahaan(Irhami Fahmi, 2013).

Analisis SWOT adalah analisis informasi yang diperoleh,dicari,atau diterima dari berbagai sumber hasil hasil dari pertanyaan: Apa yang sedang terjadi, kenapa terjadi, dimana terjadi, dan kapan terjadi, yang semuanya berasal dari internal perusahaan eksternal berkaitan dengan usaha perusahaan(Etika Sabariah, 2016).

Definisi analisis SWOT yang lainnya yaitu sebuah bentuk analisis situasi dan juga kondisi yang bersifat deskriptif (memberi suatu gambaran). Analisis ini menenmpatkan situasi dan juga kondisi sebagai faktor masukan, lalu kemudian dikelompokkan menurut kontribusinya masing-masing. SWOT adalah singkatan dari Strength (kekuatan), Weaknesses (kelemahan), Opportunities (peluang), Threats 
(hambatan)(Marimin, 2004). Keputusan strategis perusahaan perlu pertimbangan faktor internal yang mencakup kekuatan dan kelemahan maupun faktor eksternal yang mencakup peluang dan ancaman. Oleh karena itu perlu adanya pertimbanganpertimbangan penting untuk analisis SWOT(Freddy Rangkuti, 2004).

1. Strenght (kekuatan) yaitu situasi ataupun kondisi yang merupakan kekuatan dari suatu organisasi atau perusahaan pada saat ini yang yang membutuhkan tingkat tekhnologi dan juga kualitas yang lebih maju.

2. Weaknesses(kelemahan) yaitu situasi ataupun kondisi yang merupakan kelemahan dari suatu organisasi atau perusahaan pada saat ini. Merupakan cara menganalisis kelemahan di dalam sebuah perusahaan ataupun organisasi yang menjadi kendala yang serius dalam kemajuan suatu perusahaan atau organisasi.

3. Opportunity (peluang) yaitu, situasi atau kondisi yang merupakan peluang diluar suatu organisasi atau perusahaan dan memberikan peluang berkembang bagi organisasi dimasa depan. Cara ini adalah untuk mencari peluang ataupun terobosan yang memungkinkan suatu perusahaan ataupun organisasi bisa berkembang dimasa yang akan datang.

4. Threats (Ancaman) yaitu, cara menganalisis tantangan atau ancaman yang harus dihadapi oleh suatu perusahaan atau organisasi yang menyebabkan kemunduran. Jika tidak segera diatasi, ancaman tersebut akan menjadi penghalang bagi suatu usaha yang bersangkutan baik dimasa sekarang maupun masa yang akan datang.

\section{Tujuan dan Manfaat Analisis SWOT}

Tujuan dan manfaat analisis SWOT adalah untuk memadukan empat faktor atau komposisi secara tepat tentang bagaimana mempersiapkan kekuatan (strangth), mengatasi kelemahan (weaknes), menemukan peluuang (opportunity) dan strategi menghadapi berbagai ancaman (threath). Metode analisis SWOT bisa dianggap sebagai metode analisis yang paling dasar, yang bermanfaat untuk melihat suatu topik ataupun suatu permasalahan. Ketika teknik ini dapat dijalankan secara tepat dengan menggabungkan keempat elemen tersebut maka kesempurnaan meraih visi dan misi program yang direncanakan tentunya akan bertujuan lebih dengan hasil yang optimal. Analisis ini berperan sebagai alat meminimalisasikan kelemahan yang terdapat dalam suatu perusahaan organisasi serta menekan dampak ancaman yang timbul dan harus dihadapi. 


\section{Faktor yang Mempengaruhi Analisis SWOT}

Analisis SWOT adalah identifikasi berbagai faktor secara sistematis untuk merumuskan strategi perusahaan. Analisis ini didasarkan pada logika yang dapat memaksimalkan kekuatan (Stregth) dan peluang (Opportunities), namun secara bersamaan dapat meminimalisir kelemahan (Weaknesess) dan ancaman (Threats). Proses pengambilan keputusan strategis selalu berkaitan dengan pengembangan misi, tujuan, strategi, dan kebijakan perusahaan.

Dalam menyusun strategi Analisis SWOT tentu ada yang mempengaruhi komponen analisis SWOT faktor tersebut dapat berasal dalam (faktor internal), dan berasal dari luar (faktor eksternal).

\section{Faktor Internal}

Faktor internal adalah faktor yang berasal dari dalam perusahaan dimana terdapat dua komponen yaitu kekuatan dan kelemahan. Kedua komponen tersebut berdampak pada lebih baiknya suatu penelitian jika kekuatan lebih besar dari pada kelemahan. Sehingga, jika kekuatan internal perusahaan ini menjadi lebih maksimum maka akan memberikan hasil penelitian yang jauh lebih baik.

\section{Faktor Eksternal}

Dalam faktor eksternal, apa yang diteliti tidak secara langsung terlibat. Faktor eksternal terbagi menjadi dua bagian yaitu ancaman dan peluang. Adanya kedua komponen tersebut maka akan memberikan data yang perlu dimasukkan dalam jurnal penelitian akan menghasilkan strategi untuk menghadapinya.

\section{StrategiPersaingan Bisnis}

Strategi adalah alat untuk mencapai tujuan jangka panjang yang mencakup ekspansi geografis, diversifikasi, akuisi, pengembangan produk, penetrasi pasar, pengurangan bisnis, divestasi, likuidasi, dan joint venture. Strategi ini adalah tindakan potensial yang membutuhkan keputusan manajemen tingkat atas dan sumber daya perusahaan dengan jumlah yang besar(Dafid Fred R, 2011).

Strategi merupakan upaya pengembangan posisis kompetitif perusahaan ditengah persaingan usaha. Sementara itu, strategi adalah seperangkat tujuan dan rencana tindakan yang spesifik, yang apabila dicapai akan memberikan keunggulan kompetitif yang diharapkan. Strategi meliputi identifikasi dan implementasian tujuan dan rencana tindakan tersebut. Strategi membutuhkan informasi untuk membuat 
keputusan strategi yang tepat berkaitan dengan pemilihan produk, metode produksi, saluran pemasaran, dan hal lain yang bersifat jangka panjang.

Strategi juga dikayakan sebagai pola tindakan utama yang dipilih untuk mewujudkan tujuan perusahaan. Strategi merupakan seperangkat tujuan dan rencana tindakan yang spesifik, yang apabila dicapai akan memberikan keunggulan kompetitif yang diharapkan. Dengan kata lain, strategi merupakan jawaban atas pertanyaan bagaimana suatu perusahaan dapat mencapai tujuan yang ditetapkan, dengan demikian strategi adalah segala langkah yang diperlukan perusahaan untuk mencapai tujuan yang ditetapkan.

Manajemen Strategis adalah suatu rencana yang disusun dan dikelola dengan memperhitungkan berbagai sisi dengan tujuan agar pengaruh rencana tersebut bisa memberikan dampak positif bagi organisasi tersebut secara jangka panjang. Manajemen strategi bertujuan untuk menciptakan langkah-langkah efektif dan efisien dalam mencapai tujuan. Harta karun yang paling berharga di era globalisasi ini adalah:faktor produksi, informasi, ilmu pengetahuan, skill atau kemampuan kerja, modal dan jaringan, serta tepat waktu (up date) dan loyalitas, dimana semua itu dibangun dengan daya analisis yang tinggi, kerja keras, hubungan baik, kepercayaan, ketelitian, dan lain sebagainya. Harta karun tersebut adalah modal yang akan digunakan dalam manajemen strategis, dimana tujuan manajemen strategis adalah memenangkan sebuah kompetiisi, dengan menciptakan efisiensi dan efektivitas dengan harta karun tersebut serta menambah nilai dengan berbagai macam inovasi(Etika Sabariah, 2016).

Perencanaan Strategis merupakan proses analisis, perumusan dan evaluasi strategi-strategi. Kegiatannya meliputi pengamatan secara hati-hati persaingan, peraturan, tingkat inflasi, siklus bisnis, keinginan dan harapan konsumen, serta faktorfaktor lain yang dapat mengidentifikasi peluang serta ancaman.

\section{Prinsip-Prinsip Islam}

Terdapat beberapa prinsip syari'ah yang menjadi pembeda dengan sisitem ekonomi lainnya. Prinsip-prinsip ini memeberikan landasan dan panduan dalam menjalankan aktifitas perekonomian secara syari'ah. Ada beberapa prinsip Islam yang perlu diperhatikan, yaitu:

1. Prinsip Tauhid 
Konsep tauhid (dimensi vertikal) berarti Allah sebagai penentu kehidupan menetapkan batas-batas tertentu atas perilaku manusia sebagai khalifah, untuk memberikan manfaat pada individu tanpa mengorbankan hak-hak individu lainnya.Dengan mengintegrasikan aspek religius keagamaan dengan aspek ekonomi akan menimbulkan perasaan dalam diri manusia bahwa ia akan selalu merasa direkam segala aktifitas kehidupannya, termasuk dalam aktifitas berekonomi sehingga dalam melakukan segala aktifitas bisnis tidak akan mudah menyimpang dari segala ketentuannya. Ini berarti konsep tauhid akan memiliki pengaruh yang paling mendalam terhadap seorang muslim(Rafik Isa Beekun, 2004).

\section{Khilafah}

Dalam berbisnis perlu adanya intelektualitas atau kecerdasan untuk menjalankan strategi bisnis sesuai dengan ketentuan-ketentuan yang berlaku, sehingga menghasilkan keuntungan yang memadai. Dengan kecerdasan pula, seorang pebisnis mampu mewaspadai dan menghindari berbagai bentuk kejahatan non etis yang mungkin dilancarkan oleh lawan-lawan bisnisnya(Agus Arijanto, 2011). Setiap pembisnis memiliki intelektualitas atau ide masing-masing untuk mengembangkan bisnisnya. Sebagai khalifah di bumi manusia memiliki kebebasan untuk mengarahkan kehidupannya pada tujuan yang diingankannya. Kebebasan berarti bahwa pembisnis sebagai individu dan kolektif mempunyai kebebasan penuh untuk melakukan aktifitas bisnis, namun kebebasan tersebut bukan berarti kebebasan tanpa batas.

\section{Prinsip Ibadah}

Prinsip Ibadah Islam adalah ketika dapat berbisnis tidak semata-mata hanya untuk mendapatkan profit atau keuntungan, melainkan segala aktifitas bisnis diniatkan sebagai bentuk ibadah kepada Allah.

\section{Prinsip Tazkiyah}

Menerapkan prinsip kejujuran, keadilan serta keterbukaan dalam berbisnis merupakan hal yang sangat penting. Karena hal tersebut dapat mempengaruhi tingkat kepercayaan nasabah terhadap produk yang ditawarkan. Dalam hal ini juga dimaksud agar bisnis dapat bertahan dalam jangka waktu yang panjang serta mampu bersaing dengan perusahaan lain.Keterbukaan berarti kewajiban bagi para pengelola untuk menjalankan prinsip keterbukaan dalam proses pengambilan keputusan dan 
penyampaian informasi. Keterbukaan dalam menyampaikan informasi juga mengandung arti bahwa informasi yang disampaikan harus lengkap, benar dan tepat waktu kepada semua pemangku kepentingan. Tidak boleh ada yang dirahasiakan, disembunyikan, ditutup-tutupi atau ditunda-tunda pengungkapannya(Sukrisno Agoes dan I Cenik Ardana, 2013).

5. Prinsip Ihsan

Semua keputusan dan tindakan harus menguntungkan manusia baik di dunia maupun di akhirat, selain haal itu seharusnya tidak dilakukan. Islam tidak membenarkan setiap tindakan yang dapat menimbulkan kerusakan terhadap diri sendiri, masyarakat, bahkan makhluk lain seperti binatang, tumbuhan, dan alam.

\section{METODE PENELITIAN}

Urgensitas metode dalam penelitian ini adalah untuk mempermudah memperoleh data yang valid dan dapat membantu ketajaman analisis data. Adapun jenis Penelitian ini menggunakan metode kualitatif, karena permasalahan yang akan diteliti belum jelas, holistic, kompleks, dinamis dan penuh makna.

\section{Sumber Data}

Menurut teori penelitian ini kualitatif, agar penelitiannya betul-betul berkualitas, data yang dikumpulkan harus lengkap. Selain bersifat penelitian lapangan, sumber data yang digunakan peneliti dalam hal ini bisa melalui data primer dan sekunder.(Sugiono, 2012)

Sumber data Primer peneliti peroleh dari hasil interview, didalam penelitian ini yang menjadi data primer adalah data yang diperoleh langsung dari BMT NU Pusat di Sumenep. Sedangkan data sekunder peneliti peroleh dari telaah buku-buku referensi yang relevan dengan teori.

\section{TeknikPengumpulan Data}

Secara umum dalam penelitian kualiatif ada empat macam teknik pengumpulan data, yaitu observasi, wawancara, dan dokumentasi.

1. Metode observasi

Metode Observasi adalah metode yang digunakan dengan cara melakukan pengamatan langsung dan pencatatan secara sistematis terhadap fenomena-fenomena 
yang diselidiki. Melalui metode observasi ini peneliti akan mengumpulkan data berkaitan dengan persoalan yang diteliti dan sumber data peneliti jumpai.

2. Metode Interview.

Interview atau wawancara diartikan dengan suatu percakapan tanya jawab lisan antara dua orang atau lebih yang duduk berhadapan secara fisik dan didasarkan pada suatu masalah tertentu.

3. Metode Dokumentasi.

Dokumentasi merupakan laporan tertulis dari berbagai kondisidi suatu istansi yang isinya terdiri dari penjelasan serta pemikiran tentang suatu peristiwa dan proses penjabaran dan penyelesaian peristiwa tersebut. Melalui metode ini peneliti akan menggali data terkait gambaran umum tentang Analisis SWOT BMT NU Pusat di Sumenep dalam menghadapi persaingan pasar.

\section{Teknik Analisis Data}

Dalam penelitian kualitatif analisis data dilakukan pada saat proses pengumpulan data yang sedang berlangsung, dan dilakukan setelah data terkumpul dalam beberapa priode. Peneliti akan melakukan analisis terhadap jawaban informan. Menurut Miles dan Huberman, ada tiga aktivitas dalam analisis data, yaitu data reduction, data display, dan conclusion drawing/verificatio.

\section{Pengecekan Keabsahan Data}

Keabsahan data merupakan cara yang sangat urgen untuk pengecekan kesahihan (validitas) dan keterandalan (reliabilitas) data. Peneliti merupakan kerja ilmiah, untuk melakukan ini mutlak di tuntut secara objektivitas, untuk memenuhi kriteria ini dalampenelitian maka kesahihan (validitas) dan keterandalan (reliabilitas) harus dipenuhi, kalau tidak maka proses penelitian itu perlu di pertanyakan keilmiahannya.(Iskandar, 2008)

Dalam sebuah penelitian kualitatif keilmiahan merupakan faktor utama, menjaga keilmiahan tersebut dapat dilihat data yang ada, karena kesalahan mungkin saja terjadi dalam pencarian data, sedangkan data biasa terjadi dari dalam penelitian sendiri dan mungkin juga terjadi dari informan.(Lexy J Moleong, 2014)

\section{HASIL DAN PEMBAHASAN}

Strategi Analisis SWOT pada BMT NU Pusat Gapura

Jurnal al-Idārah | 103 
Sesuai dengan visinya "Terwujudnya BMT NU yang jujur, amanah dan profesional dalam membangun ekonomi umat." Maka salah satu kunci terpenting bagi BMT NU untuk mewujudkan visi tersebut adalah dengan melakukan Analisis SWOT, sebagai salah satu modal perusahaan, BMT NU berupaya melakukan perbaikanperbaikan yang berkesinambungan guna untuk mengembangkan kualitas produkproduknya.Kegiatan yang paling penting dalam proses analisis SWOT adalah memahami seluruh informasi yang terdapat pada suatu kasus, menganalisis situasi untuk mengetahui isu apa yang sedang terjadi, dan memutuskan tindakan apa yang harus segera dilakukan untuk memutuskan masalah.

Analisis SWOT adalah identifikasi berbagai faktor secara sistematis untuk merumuskan strategi perusahaan. Analisis ini didasarkan pada logika yang dapat memaksimalkan kekuatan (Stregth) dan peluang (Opportunities), namun secara bersamaan dapat meminimalisir kelemahan (Weaknesess) dan ancaman. Proses pengambilan keputusan strategis selalu berkaitan dengan pengembangan misi, tujuan, strategi, dan kebijakan perusahaan.

Dalam strategi analisis SWOT berkaitan erat dengan kegiatan yang dilakukan oleh BMT NU Gapura, misalnya melakukan strategi pemasaran. Dalam strategi pemasaran meliputi empat variabel dalam bauran pemasaran, yaitu:

1. Strategi Dalam Bidang Produk

a. Untuk penyaluran dana yaitu: Bai Bits Tsamani Al-Ajil(BBA), Mudharabah, Murabahah, Musyarakah, Al-Qardul Hasan dan Rahn.

b. Untuk produk jasa yaitu: transfer uang keseluruh Bank, pembayaran rekening PLN, Telephone dan Internet, pembayaran biaya pendidikan perguruan tinggi, dan sewa mobil.

c. Untuk tabungan yaitu: SIAGA(Simpanan Anggota), SIDIK Fathanah(Simpanan Pendididkan Fathanah), SAJADAH (Simpanan Berjangka Wadi`ah Berhadiah), SIBERKAH (Simpanan berjangka Mudharabah), SAHARA (Simpanan Haji Dan Umrah), SABAR (Simpanan Lebaran), TABAH (Tabungan Mudharabah), TARAWI (Simpanan Ukhrawi).

Sebagaimana fakta yang ada di BMT NU Pusat Gapura Sumenep hingga saat ini pihak BMT NU terus menciptakan produk baru yang dijadikan sebagai kekuatan yang dimiliki oleh pihak BMT NU serta untuk dapat bertahan dalam menghadapi persaingan 
bisnis. Menurut peneliti produk yang ditawarkan oleh pihak BMT NU Pusat Gapura Sumenep bukan berbentuk barang, namun berbentuk jasa yang mengandung manfaat namun tidak menghasilkan kepemilikan tertentu. Serta BMT NU berupaya untuk mempertahankan kelangsungan hidup produk dengan cara terus melakukan pengembangan, berhasil atau tidaknya pengembangan produk ini sering dipengaruhi oleh timingnya yang tepat atau tidak. Oleh karena itu, manajer pemasaran dengan manajer produksi saling bekerja sama agar mampu mengantisipasi pemanfaatan tekhnologi baru yang sesuai dengan selera konsumen.

\section{Strategi Dalam Bidang Promosi}

Promosi yang dilakukan oleh BMT NU dalam memasarkan produk-produk nya adalah dengan cara:

a. Melalui periklanan, yaitu promosi yang dilakukan dalam bentuk gambar atau katakata yang tertuang dalam spanduk, brosur, dan lain-lain.

b. Melalui penjualan pribadi, yaitu promosi yang dilakukan karyawan BMT NU dalam melayani, mensosialisasikan, atau menjelaskan kelebihan produk-produk kepada nasabah yang datang langsung ke BMT NU Gapura.

c. Melaui publisistas, promosi dengan cara menjadi sponsor untuk kegiatan-kegiatan yang membutuhkan dana, dan membuka stand dikegiatan tersebut, dengan menerima mahasiswa magang dan observasi juga merupakan salah satu cara mempromosikan BMT NU Gapura.

Promosi yang dilakukan dengan publisistas melalui kegiatan amal yang dilakukan, diharapkan agar masyarakat dapat melihat bahwa BMT NU peduli akan masyarakat yang kurang mampu, dan peduli akan kegiatan positif yang dilakukan masyarakat.Sebagaimana fakta yang ada di lapangan, strategi yang diterapkan oleh pihak BMT NU Pusat Gapura Sumenep dengan cara membangun kemitraan yang baik dengan pihak-pihak yang telah ada sebelumnya seperti Lembaga Nahdhatul Ulama yang berlatar belakang syari'ah. Hal ini juga merupakan peluang yang dapat digunakan oleh pihak BMT NU Pusat Gapura Sumenep yang menerapkan analisis SWOT secara tepat. Sehingga menghantarkan BMT NU kepada puncak kesuksesan. Menurut peneliti bahwa pada BMT NU dalam mempromosikannya ialah dengan cara melakukan doortodoor selain itu BMT NU membangun relasi kepada lembaga-lembaga yang berbasis syari'ah 
seperti pada Ibu-Ibu Fatayat NU untuk menawarkan produk-produk yang dimiliki oleh pihak BMT NU.

3. Strategi Dalam Bidang Harga

a. Untuk penghimpunan dan bagi hasil yang ditetapkan BMT NU lebih tinggi dari pada lembaga keuangan lainnya.

b. Untuk produk pembiayaan lainnya bagi hasil yang ditetapkan BMT NU yaitu kecil.

Sebagaimana fakta yang terjadi pada BMT NU pada produk pembiayaan sistem bagi hasil yang diterapkan lebih rendah sedangkan dalam produk penghimpun dana bagi hasil yang ditawarkan lebih tinggi dibandingkan lembaga keuangan lainnya. Sehingga dapat membantu perekonomian masyarakat khususnya menengah ke bawah. Menurut peneliti harga yang telah ditetapkan oleh pihak BMT NU telah berdasarkan pertimbangan kemampuan masyarakat yang mayoritas perekonomiannya menengah kebawah. Sehingga, tidak memberatkan masyarakat dan menciptakan empati dihati masyarakat.

\section{Strategi Dalam Bidang Tempat}

Dalam melakukan bauran pemasaran dalam aspek tempat yang dilakukan BMT NU adalah membuka kantor cabang diberbagai cabang diberbagai daerah-daerah untuk mempermudah masyarakat didalam bertransaksi dengan BMT NU. Yaitu di BatangBatang, Peragaan, Rubaru, Dungkek, dan Bluto, Manding, Lenteng, Ganding, Saronggih, Batuputih, Gayam Sepudi, dan Talango-Poteran.BMT NU Gapura Sumenep adalah salah satu lembaga keuangan yang sangat pesat berkembangnya. Hal itu dikarenakan berkat kerja keras anggota dan BMT NU sangat cerdik didalam melakukan strategi pemasarannya. Sehingga, sampai saat ini BMT NU masih terus berkembang.Sebagaimana fakta yang terjadi di lapangan bahwa dalam melakukan bauran pemasaran dalam aspek tempat yang dilakukan BMT NU adalah membuka kantor cabang diberbagai daerah-daerah untuk mempermudah masyarakat didalam bertransaksi dengan BMT NU. Yaitu di Batang-Batang, Peragaan, Rubaru, Dungkek, dan Bluto, Manding, Lenteng, Ganding, Saronggih, Batuputih, Gayam Sepudi, dan Talango-Poteran, dan banyak juga yang berada di luar Kota Sumenep.Menurut peneliti setelah melakukan penelitian tentang BMT NU Pusat Gapura Sumenep dan Strategi Analisis SWOT, dapat dikatakan bahwa Analisis SWOT yang dilakukan oleh pihak BMT NU Pusat Gapura Sumenep sudah cukup bagus dan baik serta dapat dikatakan 
berhasil untuk dapat bertahan menghadapi para pesaing. Hal ini dibuktikan dengan adanya cabang BMT NU yang terletak di beberapa daerah, dan terus meningkatkan reproduksinya dari tahun ke tahun.

\section{Strategidalam Menghadapi Persaingan Bisnis pada BMT NU Pusat Gapura Sumenep}

Dalam menyusun strategi Analisis SWOT tentu ada yang mempengaruhi komponen analisis SWOT faktor tersebut dapat berasal dalam (faktor internal), dan berasal dari luar (faktor eksternal).Terdapatbeberapa prinsip syari'ah yang menjadi pembeda dengan sisitem ekonomi lainnya. Prinsip-prinsip ini memeberikan landasan dan panduan dalam menjalankan aktifitas perekonomian secara syari'ah. Ada beberapa prinsip Islam yang perlu diperhatikan, yaitu:

1. Prinsip Tauhid

Konsep tauhid (dimensi vertikal) berarti Allah sebagai penentu kehidupan menetapkan batas-batas tertentu atas perilaku manusia sebagai khalifah, untuk memberikan manfaat pada individu tanpa mengorbankan hak-hak individu lainnya.Dengan mengintegrasikan aspek religius keagamaan dengan aspek ekonomi akan menimbulkan perasaan dalam diri manusia bahwa ia akan selalu merasa direkam segala aktifitas kehidupannya, termasuk dalam aktifitas berekonomi sehingga dalam melakukan segala aktifitas bisnis tidak akan mudah menyimpang dari segala ketentuannya. Ini berarti konsep tauhid akan memiliki pengaruh yang paling mendalam terhadap seorang muslim.BMT NU Pusat Gapura dalam aktifitas bisnisnya sangat memperhatikan konsep tauhid ini sebagai bentuk hubungan yang baik dengan sang pencipta.

2. Khilafah (Intelektualitas-Kehendak Bebas Tanggung Jawab Dan Akuntabilitas).

Dalam berbisnis perlu adanya intelektualitas atau kecerdasan untuk menjalankan strategi bisnis sesuai dengan ketentuan-ketentuan yang berlaku, sehingga menghasilkan keuntungan yang memadai. Dengan kecerdasan pula, seorang pebisnis mampu mewaspadai dan menghindari berbagai bentuk kejahatan non etis yang mungkin 
dilancarkan oleh lawan-lawan bisnisnya. Setiap pembisnis memiliki intelektualitas atau ide masing-masing untuk mengembangkan bisnisnya. Sebagai khalifah di bumi manusia memiliki kebebasan untuk mengarahkan kehidupannya pada tujuan yang diingankannya. Kebebasan berarti bahwa pembisnis sebagai individu dan kolektif mempunyai kebebasan penuh untuk melakukan aktifitas bisnis, namun kebebasan tersebut bukan berarti kebebasan tanpa batas. Dalam berbisnis, BMT NU Pusat Gapura membiarkan pembisnis lain menawarkan produk yang sama dan bersaing secara sehat.

3. Prinsip Ibadah (Penyerahan Total).

PrinsipIbadah Islam adalah ketika dapat berbisnis tidak semata-mata hanya untuk mendapatkan profit atau keuntungan, melainkan segala aktifitas bisnis diniatkan sebagai bentuk ibadah kepada Allah. Begitu juga prinsip yang diterapkan oleh BMT NU Pusat Gapura yang lebih memasrahkan segala usahanya kepada Allah SWT.Dengan begitu, dalam bisnisnya BMT NU Pusat Gapura Sumenep memasrahkan hasil usahanya kepada Allah SWT, dengan memegang teguh prinsip kejujuran, amanah, dan kualitas, baik dari segi produk maupun pelayanan.

4. Prinsip Tazkiyah (kejujuran, keadilan, keterbukaan)

Menerapkan prinsip kejujuran, keadilan serta keterbukaan dalam berbisnis merupakan hal yang sangat penting. Karena hal tersebut dapat mempengaruhi tingkat kepercayaan nasabah terhadap produk yang ditawarkan. Dalam hal ini juga dimaksud agar bisnis dapat bertahan dalam jangka waktu yang panjang serta mampu bersaing dengan perusahaan lain.Keterbukaan berarti kewajiban bagi para pengelola untuk menjalankan prinsip keterbukaan dalam proses pengambilan keputusan dan penyampaian informasi. Keterbukaan dalam menyampaikan informasi juga mengandung arti bahwa informasi yang disampaikan harus lengkap, benar dan tepat waktu kepada semua pemangku kepentingan. Tidak boleh ada yang dirahasiakan, disembunyikan, ditutup-tutupi atau ditunda-tunda pengungkapannya.

Dalam konteks bisnis, kejujuran dan keterbukaan dimaksudkan sebagai niat, sikap serta perilaku benar yang meliputi proses mencari atau memperoleh komoditas pengembangan maupun dalam proses upaya meraih dan meningkatkan keuntungan. Dalam hal ini, BMT NU Pusat Gapura menjelaskan produk kepada konsumen sesuai dengan kondisinya. Prinsip keadilan menuntut agar setiap orang diperlakukan secara sama sesuai dengan aturan yang adil dan kriteria yang rasional objektif dan dapat 
dipertanggung jawabkan. Keadilan berarti tidak ada pihak yang dirugikan hak dan kepentingannya.

5. Prinsip Ihsan

Semua keputusan dan tindakan harus menguntungkan manusia baik di dunia maupun di akhirat, selain haal itu seharusnya tidak dilakukan. Islam tidak membenarkan setiap tindakan yang dapat menimbulkan kerusakan terhadap diri sendiri, masyarakat, bahkan makhluk lain seperti binatang, tumbuhan, dan alam.Dalam prinsip ini BMT NU Pusat Gapura Sumenep membangun hubungan baik dengan nasabah.Pelaku bisnis menurut Islam, tidak hanya mengejar keuntungan sebanyak-banyaknya, tetapi juga beriorintasi kepada sikap ta'awun (menolong orang lain) sebagai implikasi sosial kegiatan bisnis. Tegasnya berbisnis bukan mencari keuntungan material semata, tetapi didasari kesadaran memberi kemudahan bagi orang lain dengan menjual barang.BMT NU Pusat Gapura dalam bisnisnya memiliki tujuan untuk berbuat baik dan sebagai penyalur untuk memenuhi kebutuhan sesama.

Dalam berbisnis, penting untuk membangun hubungan yang baik dengan orang lain, terlebih dengan sesama karyawan dan nasabah. Dalam hal ini, BMT NU Pusat Gapura Sumenep telah menjalankan bisnisnya sesuai prinsip ihsan sesuai dengan ajaran Islam.Dari apa yang telah dipaparkan diatas, dapat penulis simpulkan bahwa pandangan Islam mengenai Analisis SWOT dalam menghadapi persaingan pada BMT NU Pusat Gapura adalah tetap berpegang teguh pada prinsip-prinsip Islam. Dari fakta yang ada, BMT NU Pusat Gapura Sumenep sejak berdirinya hingga saat ini tercatat telah memiliki cabang sejumlah 62 kantor yang tersebar di sebelas Kabupaten, hal ini merupakan salah satu fakta yang membuktikan bahwa BMT NU Pusat Gapura Sumenep telah mampu bertahan dalam menghadapi persaingan bisnis.

Menurut Nana Herdiana Abdurrahman mengatakan bahwa persaingan bukan berarti upaya mematikan pesaing, tetapi dilakukan untuk memberikan sesuatu yang terbaik dari usaha bisnis dan janganlah menganggap pesaing sebagai musuh, tetapi anggaplah sebagai saudara anda. Memang, anda perlu, bahkan harus mengantisipasi pesaing yaitu dengan mengembangkan analisis bisnis dan analisis pokok melalui penataan keadaan produk dan jasa pesaing. Untuk mencapai keberhasilan, seorang pebisinis muslim harus memiliki profesionalisme yang tinggi. Profesionalisme dalam 
bisnis syari'ah tidak hanya memiliki karakteristik seorang pengusaha atau pedangang, tetapi juga harus memiliki karakteristik syari'ah.

Untuk memantapkan daya saing dan mencapai keberhasilan, diperlukan strategi yang bukan hanya bertujuan mendapatkan dan meningkatkan laba, melainkan juga meningkatkan keimanan atau rezeki yang kita peroleh benar-benar diridhoi oleh Allah SWT. Menurut opini penulis, pada BMT NU Pusat Gapura Sumenep dalam menghadapi persaingan bisnis memprioritaskan kualitas, juga pelayanan yang baik bagi masyarakat, sehingga dapat mempengaruhi mindset pemikiran masyarakat tentang BMT NU Pusat Gapura Sumenep. Hal ini dapat dijadikan sebagai pertahanan dalam menghadapi persaingan bisnis di era Millenial saat ini.

\section{KESIMPULAN}

Analisis SWOT adalah identifikasi berbagai faktor secara sistematis untuk merumuskan strategi perusahaan. Analisis ini didasarkan pada logika yang dapat memaksimalkan kekuatan (Stregth) dan peluang (Opportunities), namun secara bersamaan dapat meminimalisir kelemahan (Weaknesess) dan ancaman. Proses pengambilan keputusan strategis selalu berkaitan dengan pengembangan misi, tujuan, strategi, dan kebijakan perusahaan. Didalam menentukan strategi analisis SWOT dalam menghadapi persaingan harus juga diperhatikan analisis lingkungan dan internal perusahaan melalui analisis keunggulan dan kelemahan perusahaan, serta analisis kesempatan dan ancaman yang dihadapi perusahaan dari lingkungannya.

Strategi dalam menghadapi persaingan bisnis dapat dilihat dari beberpa hal. Begitupun terdapatbeberapa prinsip syari'ah yang menjadi pembeda dengan sisitem ekonomi lainnya. Prinsip-prinsip ini memberikan landasan dan panduan dalam menjalankan aktifitas perekonomian secara syari'ah. Ada beberapa prinsip Islam yang perlu diperhatikan, yaitu:Prinsip Tauhid, Khilafah, Prinsip Ibadah, Prinsip Tazkiyah, Prinsip Ihsan

\section{DAFTAR PUSTAKA}

Agus Arijanto. (2011). Etika Bisnis Bagi Pelaku Bisnis. Jakarta: Raja Grafindo Persada. Dafid Fred R. (2011). Strategi Manajemen: Manajemen Strategi Konsep. Bandung : Salemba Empat.

Etika Sabariah. (2016). Manajemen Strategis. Yokyakarta: Pustaka Belajar. 
Freddy Rangkuti. (2004). Analisi SWOT Teknik Membedah Kasus Bisnis. Jakarta: PT. Gramedia Pustaka Utama.

Irhami Fahmi. (2013). Kewirausahaan : Teori, Kass dan Solusi. Bandung: Alfabeta.

Iskandar . (2008). Metode Penelitian Pendidikan Sosial. Jakarta: GP Press.

Lexy J Moleong. (2014). Metode Penelitian Kualitatif. Bandung: Alfabeta.

Marimin. (2004). Teknik dan Aplikasi Pengambilan Keputusan Kriteria Majemuk.

Bogor: Grasindo.

Nana Herdiana Abdurrahman. (2013). Manajemen Bisnis Syari'ah \& Kewirausahaan.

Bandung: CV. Pustaka Setia.

Rafik Isa Beekun. (2004). Etika Bisnis Islam. Yogyakarta: Pustaka Pelajar.

Sugiono. (2018). Metode Penelitian Kuantitatif dan R\&D. Bandung: Alfabeta.

Sugiono. (2012). Metode Penelitian Pendidikan. Bandung: Alfabeta.

Sukrisno Agoes dan I Cenik Ardana. (2013). Etika Bisnis dan Profesi. Jakarta: Salemba Empat.

Veithzal Rivai. (2004). Manajemen Sumber Daya Manusia Untuk Perusahaan: Dari Teori ke Praktik. Jakarta: PT. Raja Grafindo Persada.

Veitzal Rival Zainal dkk. (2014). Manajemen Sumber Daya Manusia. Jakarta: PT. Raja Grafindo Persada. 